\title{
THE SPECTRUM OF COMPUTERIZED TOMOGRAPHY (CT) FINDINGS IN CENTRAL NERVOUS SYSTEM (CNS) INFECTION DUE TO Cryptococcus neoformans VAR. gattii IN IMMUNOCOMPETENT CHILDREN
}

\author{
Maria do Perpétuo Socorro Costa CORRÊA(1), Luiz Carlos SEVERO(2), Flávio de Mattos OLIVEIRA(3), Klaus IRION(4) \& Alberto Thomaz LONDERO(5)
}

\section{SUMMARY}

Cranial CT scans of eleven immunocompetent children with central nervous system (CNS) infection due to Cryptococcus neoformans var. gattii were retrospectively reviewed. These children had an average age of 8.8 years and positive culture for $C$. $n$. var. gattii in cerebrospinal fluid. The most common signs and symptoms were headache, fever, nuchal rigidity, nausea and vomiting. No normal cranial CT was detected in any patient. Hypodense nodules were observed in all patients. The remaining scan abnormalities were as follows: nine had diffuse atrophy, six had hydrocephalus, and five had hydrocephalus coexistent with diffuse atrophy.

KEYWORDS: Cryptococcosis; Cryptococcus neoformans; Cryptococcus neoformans var. gattii; Childhood; Meningitis.

\section{INTRODUCTION}

On the basis of biochemical studies, the asexual anamorph state of Cryptococcus neoformans can be divided into two varieties: $C$. neoformans var. neoformans (serotypes A and D) worldwide distributed is isolated from soil contaminated with avian feces, in urban areas; occurs in immunosuppressed patients (opportunistic pathogen). C. neoformans var. gattii (serotypes B and C) occurs mainly in tropical and temperate climates, in soil with eucalyptus trees; has a propensity for causing disease in immunocompetent hosts (primary pathogen) $)^{4,10,15}$.

Cryptococcosis is an infrequent opportunistic pediatric infection ${ }^{2,12-}$ ${ }^{14}$. A 10-year point prevalence of cryptococcosis among HIV-infected children was of $1.4 \%{ }^{1}$. However, the Northeastern Brazilian region is a highly endemic area of cryptococcosis in children due to var. gattii ${ }^{5}$.

The lesions revealed by cranial CT scans of 11 children under 13 years of age, living in the State of Pará and affected by cryptococcosis of the CNS will be herein presented. Some comments on epidemiology of the disease will also be made.

\section{PATIENTS AND METHODS}

The cranial CT scans of eleven children under 13 years of age were retrospectively reviewed. All children had proven CNS infection caused by $C$. neoformans var. gattii. CT scan was obtained at least at the time of the diagnosis. They had been brought to hospital between January 1992 and December 2000.
The exams were performed by two different equipments, Toshiba TCT500S and Siemens Somatom AR. A protocol routine to infant was used, with $5 \mathrm{~mm}$ collimation in posterior fossae and $10 \mathrm{~mm}$ in the upper parts. Intravenous contrast agent was used routinely. All exams were reviewed by one radiologist (KI) that considered any the abnormalities found, with special attention to the presence of abnormalities in densities, mass effect, atrophy, and ventricle sizes.

CNS cryptococcosis infection was recognized by the detection of encapsulated yeasts at the microscopic examination and by the isolation in culture from the cerebrospinal fluid. The variety of the agent was identified by the characteristic color reaction produced by the fungus in the canavanine-glycine-bromothymol blue agar medium? ${ }^{7}$.

\section{RESULTS}

Eight patients were boys and three were girls aged 6 to 12 years old (average 8.8). The most common present signs and symptoms (Table 1) were headache, fever and nuchal rigidity $(\mathrm{n}=11)$; nausea and vomiting ( $\mathrm{n}$ $=10$ ). The average time from the onset of the symptoms to the diagnosis was 5.2 weeks (ranging two weeks to three months). All the eleven patients presented abnormalities in their cranial CT (Table 2). Hypodense nodules were observed in all of them. The remaining scan abnormalities were as follows: nine had diffuse atrophy, six had hydrocephalus, and five had hydrocephalus coexistent with diffuse atrophy (Figs. 1-3).

There was no correlation between CT findings and the severity of the disease or outcome.

(1) Núcleo de Medicina Tropical, Universidade Federal do Pará (UFPA), PA, Brasil.

(2) Pesquisador do CNPq; Universidade Federal do Rio Grande do Sul (UFRGS), RS, Brasil.

(3) Laboratório de Microbiologia Clínica, Instituto Especializado em Pesquisa e Diagnóstico (IPD), Santa Casa, RS, Brasil.

(4) Pavilhão Pereira Filho, Santa Casa, RS, Brasil.

(5) Universidade Federal de Santa Maria, Santa Maria, RS, Brasil.

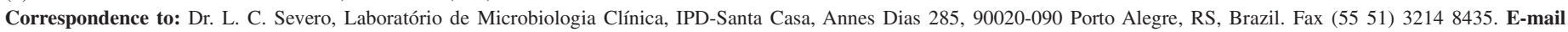
severo@santacasa.tche.br 
Table 1

Cerebral nervous system presenting symptoms and cerebrospinal fluid findings

\begin{tabular}{|c|c|c|c|c|c|}
\hline \multirow[t]{2}{*}{ No. } & \multirow[t]{2}{*}{ Age, gender } & \multirow{2}{*}{$\begin{array}{l}\text { Signs or symptoms; } \\
\text { course prior to diagnose }\end{array}$} & \multicolumn{3}{|c|}{ Cerebrospinal fluid } \\
\hline & & & White cell count $(\mu \mathrm{l})$ & Protein (mg/dl) & Glucose $(\mathrm{mg} / \mathrm{dl})$ \\
\hline 1 & $6, \mathrm{~F}$ & $\mathrm{H}, \mathrm{F}, \mathrm{NV}, \mathrm{NR}, \mathrm{S} ; 5$ weeks & 15 & 40 & 15 \\
\hline 2 & $8, \mathrm{~F}$ & $\mathrm{H}, \mathrm{F}, \mathrm{NR}, \mathrm{S} ; 2$ months & 54 & 74 & 10 \\
\hline 3 & $11, \mathrm{M}$ & H, F, NV, NR, VD; 2 weeks & 13 & 35 & 42 \\
\hline 4 & $12, \mathrm{~F}$ & H, F, NV, NR, AMS; 2 weeks & 19 & 37 & 30 \\
\hline 5 & $9, \mathrm{~F}$ & $\mathrm{H}, \mathrm{F}, \mathrm{NV}, \mathrm{NR}, \mathrm{S}, \mathrm{AMS} ; 3$ weeks & 10 & 35 & 40 \\
\hline 6 & $8, \mathrm{~F}$ & H, F, NV, NR, S, AMS; 2 months & 46 & 301 & 35 \\
\hline 7 & $10, \mathrm{~F}$ & $\mathrm{H}, \mathrm{F}, \mathrm{NV}, \mathrm{NR} ; 1$ month & 930 & 70 & 56 \\
\hline 8 & $8, \mathrm{M}$ & $\mathrm{H}, \mathrm{F}, \mathrm{NV}, \mathrm{NR} ; 5$ weeks & 85 & 51 & 68 \\
\hline 9 & $8, \mathrm{M}$ & $\mathrm{H}, \mathrm{F}, \mathrm{NV}, \mathrm{NR}, \mathrm{VD}, \mathrm{S} ; 2$ weeks & 299 & 65 & 38 \\
\hline 10 & $6, \mathrm{M}$ & $\mathrm{H}, \mathrm{F}, \mathrm{NV}, \mathrm{NR} ; 5$ weeks & 355 & 43 & 51 \\
\hline 11 & $11, \mathrm{M}$ & H, F, NV, NR, S, AMS; 3 weeks & 32 & 141 & 5 \\
\hline
\end{tabular}

$\mathrm{H}$, headache; F, fever; AMS, altered mental status; VD, visual disturbace; S, seizures; NV, nausea and vomiting; NR, nuchal rigidity;

Table 2

Clinical characteristics and cranial CT scan of children with CNS infection due to C. neoformans var. gattii

\begin{tabular}{|c|c|c|c|c|c|}
\hline No. & $\begin{array}{l}\text { Additional sites of } \\
\text { cryptococcal infection }\end{array}$ & Associated disease & Cranial CT findings & $\begin{array}{l}\text { Treatment }(*) \text {; } \\
\text { maintenance }\end{array}$ & $\begin{array}{l}\text { Outcome; } \\
\text { complication }\end{array}$ \\
\hline 1 & None & Sepsis & $\begin{array}{l}\text { Hypodense nodules, hydrocephalus, } \\
\text { and diffuse atrophy }\end{array}$ & $\operatorname{AmB}(2 \mathrm{~m})$ & Died \\
\hline 2 & Lung pneumonia & None & Hypodense nodules and hydrocephalus & $\begin{array}{l}\text { AmB, V-P } \\
\text { shunt (7m); Flu }\end{array}$ & $\begin{array}{l}\text { Cured; } \\
\text { blindness }\end{array}$ \\
\hline 3 & $\begin{array}{l}\text { Bilateral lung } \\
\text { masses }\end{array}$ & Sepsis & $\begin{array}{l}\text { Hypodense nodules, hydrocephalus, } \\
\text { and diffuse atrophy }\end{array}$ & $\mathrm{AmB}, 5-\mathrm{FC},(7 \mathrm{~m}) ; \mathrm{Flu}$ & Cured \\
\hline 4 & None & None & Hypodense nodules and diffuse atrophy & $\mathrm{AmB}, 5-\mathrm{FC},(3 \mathrm{~m})$; Flu & $\begin{array}{l}\text { Cured; } \\
\text { blindness }\end{array}$ \\
\hline 5 & None & Bacterial pneumonia & Hypodense nodules and diffuse atrophy & $\mathrm{AmB}, 5-\mathrm{FC}(1 \mathrm{~m})$ & Died \\
\hline 6 & None & None & Hypodense nodules and diffuse atrophy & $\begin{array}{l}\text { AmB, 5-FC, V-P } \\
\text { shunt }(4 \mathrm{~m}) ; \text { Flu }\end{array}$ & Cured \\
\hline 7 & None & None & Hypodense nodules and diffuse atrophy & $\mathrm{AmB}(3 \mathrm{~m}) ; \mathrm{Flu}$ & Cured \\
\hline 8 & None & Pulmonary tuberculosis & $\begin{array}{l}\text { Hypodense nodules, hydrocephalus, } \\
\text { and diffuse atrophy }\end{array}$ & $\begin{array}{l}\text { AmB, V-P } \\
\text { shunt }(2 \mathrm{~m}) ; \text { Flu }\end{array}$ & $\begin{array}{l}\text { Cured; } \\
\text { blindness }\end{array}$ \\
\hline 9 & None & None & Hypodense nodules & $\begin{array}{l}\text { AmB, V-P } \\
\text { shunt }(3 \mathrm{~m}) ; \text { Flu }\end{array}$ & $\begin{array}{l}\text { Cured; } \\
\text { blindness }\end{array}$ \\
\hline 10 & None & None & $\begin{array}{l}\text { Hypodense nodules, hydrocephalus, } \\
\text { and diffuse atrophy }\end{array}$ & AmB (3m); Flu & Cured \\
\hline 11 & None & None & $\begin{array}{l}\text { Hypodense nodules, hydrocephalus, } \\
\text { and diffuse atrophy }\end{array}$ & $\begin{array}{l}\text { AmB, V-P } \\
\text { shunt (3m); Flu }\end{array}$ & $\begin{array}{l}\text { Cured; } \\
\text { blindness }\end{array}$ \\
\hline
\end{tabular}

AmB, amphotericin B; Flu, fluconazole; 5-FC, flucytosine; V-P, ventriculoperitoneal

(*) Time in months of hospitalization using AmB with or without 5-FC; survivors received maintenance therapy with Flu, as outpatient. 

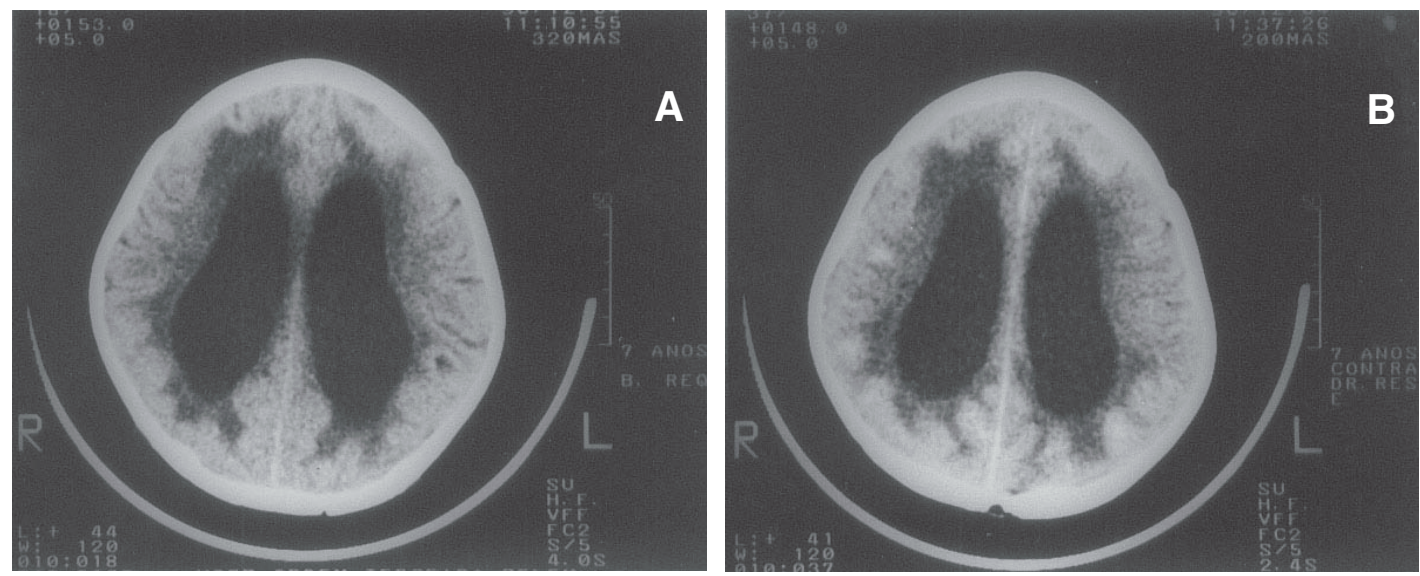

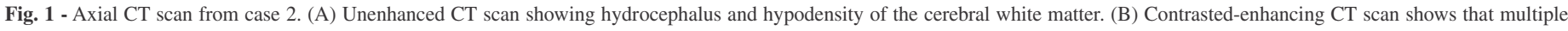
nodules became hyperdense following contrast administration.
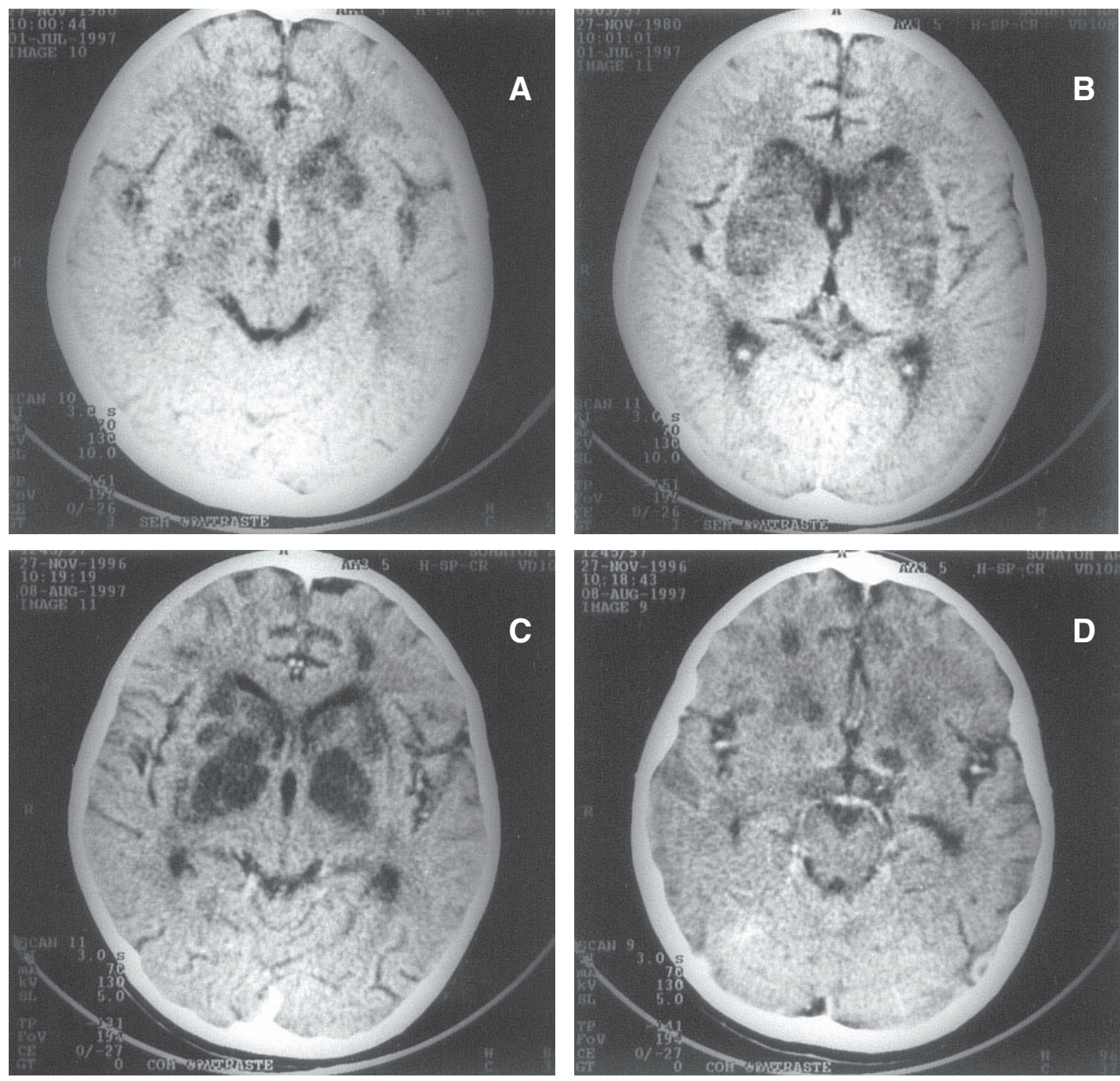

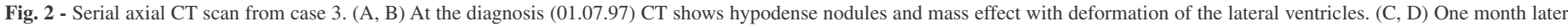
(08.08.97), following treatment, CT showing hypodensity and mass effect involving the caudate nucleous, globus pallidus, putamen, and internal capsula. 

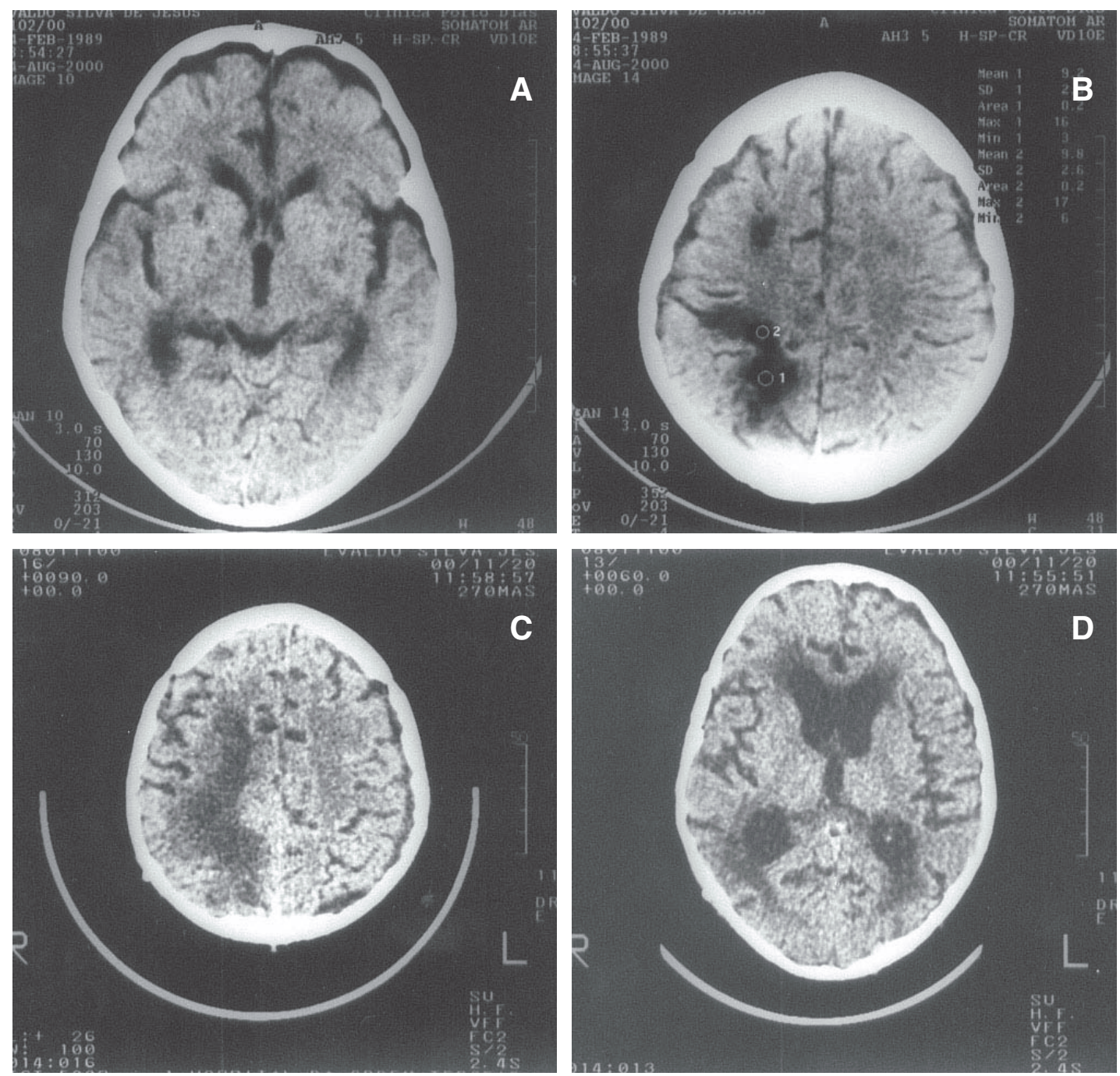

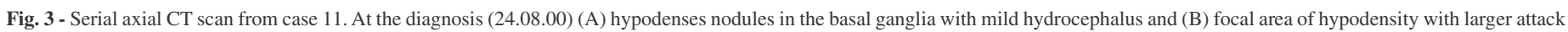
of the cerebral white matter. Three months later (20.11.00), following treatment, CT shows (C,D) progression of the attack to the white matter and cerebral diffuse atrophy.

\section{TREATMENT AND OUTCOME}

Nine patients were cured after an induction course of amphotericin $\mathrm{B}(1 \mathrm{mg} / \mathrm{Kg} /$ day $)$ with or without 5 -fluocytosine $(100 \mathrm{mg} / \mathrm{Kg} /$ day given as four divided doses at 6-hr intervals) for 2 to 7 months; then, therapy with fluconazole (200 mg/day) was given for maintainance. The remaining two patients died within two months of antifungal therapy. The average cumulated dose of amphotericin B was $1 \mathrm{~g}$. To control increased intracanial pressure, a short course (one week) of dexamethasone therapy (a daily dose of $0.6 \mathrm{mg} / \mathrm{Kg}$ in four divided doses) was used in combination with mannitol $(1 \mathrm{~g} / \mathrm{Kg})$ infused over $30 \mathrm{~min}$, and repeated when necessary at 6- to 8-hr intervals; ventriculoperitoneal shunt was performed in five patients. In five cured patients $(56 \%)$, blindness was the major complication.

\section{DISCUSSION}

The Northeastern and the Northern Brazilian regions are endemic areas of infections caused by Cryptococcus neoformans var. gattii. CAVALCANTI ${ }^{3}$ collected 124 cases of neural cryptococcosis in a nine year period (1986-1995) in the Northeastern region. Seventeen of these patients $(13.7 \%)$ were children under 10 years of age. Only 45 isolates of the 124 patients were typed, 32 of them were var. gattii. In the State of Pará CORREA et al. ${ }^{5}$ reported 19 cases of cryptococcosis of the CNS in children under 13 years of age, diagnosed in a six year period (19921998). The isolates of the last nine patients were typed, all of them, were var. gattii. With one exception, these nine patients lived in rural areas resultant of deforestation of the Amazon forest. Epidemiological, clinical, predisposing conditions, therapeutic measures and outcomes were tabulated.

To our knowledge we report the first series of cases of CNS infection due to $C$. neoformans var. gattii in immunocompetent children docummented by cranial CT scan. This study shows that the most common evident lesion is multiple hypodense nodules, mainly located in the basal gangliar region and in the cerebral white matter. Apparently 


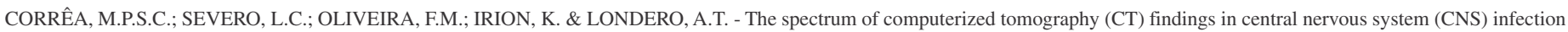
due to Cryptococcus neoformans var. gattii in immunocompetent children. Rev. Inst. Med. trop. S. Paulo, 44(5):283-287, 2002.

these lesions can progress to atrophy of the cerebral white matter, associated with ventricular dilatation and prominence of cerebral sulci, with compensatory hydrocephalus or due to hypertension. Mild changes in the cerebral cortex were observed. Neurological sequelae were frequent in the survival patients.

In this series, the lesions diminished in size or disappeared with medical therapy. These findings are an indicative of the reversibility of the lesions in some cases. Neurological permanent defects were observed in the majority of the survivors. This is a characteristic of var. gattii in healthy hosts, including adults ${ }^{15}$.

CNS is the most common involved site in cryptococcosis ${ }^{2,4,10,15}$. $C$. neoformans has affinities for it; this special tropism is due to the nutritional requirements of the fungus, since the exact and optimal nutritional needs can be supplied by the cerebrospinal fluid ${ }^{8}$ and tissue of the region of basal ganglia ${ }^{4}$. But the two varieties of the fungus (var. gattii and var. neoformans) presented some differences in the nature of CNS involvement. These differences were pointed out in studies of series of patients living in Australia and New Zealand ${ }^{4,10,15}$. However, in these countries where cryptococcosis due to var. gattii is endemic, the disease rarely occurs in children ${ }^{16}$. Nevertheless, in the Brazilian Northeastern and Northern regions, specially in the State of Pará, where cryptococcosis by var. gattii is also endemic, the disease in children is relatively frequent. The need to understand this frequence and also the nature of CNS involvement deserves more studies in these regions.

Regarding the frequency of abnormalities in the CNS detected by $\mathrm{CT}$, it must be considered as an important tool to analyse the distribution and intensity of lesions as well as treatment response.

Finally, the correlation of cryptococcal intracerebral lesion and outcome requires further study. In this way we suggest a low dose contrast-enhanced CT scan ${ }^{6,11}$ or, whenever possible, magnetic resonance images (they give contrast resolution that far exceeds that of CT) ${ }^{9}$.

\section{RESUMO}

\section{O espectro de achados tomográficos na infecção do SNC por Cryptococcus neoformans var. gattii em crianças imunocompetentes}

Os achados tomográficos de 11 crianças imunocompetentes com infecção do sistema nervoso central por Cryptococcus neoformans var. gattii foram revisados. Estas crianças tinham uma média de idade de 8,8 anos e cultivo positivo do líquor para C. neoformans var. gattii. Os sinais e sintomas mais comuns foram cefaléia, febre, rigidez de nuca, náusea e vômitos. Todas as tomografias de crânio foram anormais. Em todos os pacientes foram observados nódulos hipodensos. As demais anormalidades tomográficas foram: 9 pacientes com atrofia cerebral difusa, 6 pacientes com hidrocefalia e 5 com associação de hidrocefalia e atrofia cerebral difusa.

\section{REFERENCES}

1. ABADI, J.; NACHMAN, S.; KRESSEL, A.B. \& PIROFSKI, L. - Cryptococcosis in children with AIDS. Clin. infect. Dis., 28: 309-313, 1999.

2. CASADEVAL, A. \& PERFECT, J.R. - Cryptococcus neoformans. Washington, ASM Press, 1998.

3. CAVALCANTI, M.A.S. - Criptococose e seu agente etiológico no meio norte, Estados do Piauí e Maranhão, Brasil. Rio de Janeiro, 1997. (Dissertação de Mestrado Instituto Oswaldo Cruz).

4. CHEN, S.; SORRELL, T.; NIMMO, G. et al. - Epidemiology and host- and varietydependent characteristics of infection due to Cryptococcus neoformans in Australia and New Zealand. Australian Cryptococcal Study Group. Clin. infect. Dis., 31: 499508,2000 .

5. CORRÊA, M.P.S.; OLIVEIRA, E.C.; DUARTE, R.R.B. et al. - Criptococose em crianças no Estado do Pará, Brasil. Rev. Soc. bras. Med. trop., 32: 505-508, 1999.

6. FUJITA, N.K.; REYNARD, M.; SAPICO, F.L.; GUZE, L.B. \& EDWARDS Jr., J.E. Cryptococcal intracerebral mass lesions. The role of computed tomography and nonsurgical management. Ann. intern. Med., 94: 382-388, 1981.

7. KWON-CHUNG, K.J.; POLACHECK, I. \& BENNETT, J.E. - Improved diagnostic medium for separation of Cryptococcus neoformans var. neoformans (serotypes A and D) and Cryptococcus neoformans var. gattii (serotypes B and C). J. clin. Microbiol., 15: 535-537, 1982.

8. LITTMAN, M.L. - Cryptococcosis (Torulosis). Current concepts and therapy. Amer. J. Med., 27: 976-998, 1959

9. MISZKIEL, K.A.; HALL-CRAGGS, M.A.; MILLER, R.F. et al. - The spectrum of MRI findings in CNS cryptococcosis in AIDS. Clin. Radiol., 51: 842-850, 1996.

10. MITCHELL, D.H.; SORREL, T.C.; ALLWORTH, A.M. et al. - Cryptococcal diasease of the CNS in immunocompetent hosts: influence of cryptococcal variety on clinical manifestations and outcome. Clin. infect. Dis., 20: 611-616, 1995.

11. POPOVICH, M.J.; ARTHUR, R.H. \& HELMER, E. - CT of intracranial cryptococcosis. Amer. J. Roentgenol., 154: 603-606, 1990.

12. PY, E.A.; ALÓE, M.; BURLAMAQUI, L. et al. - Relato de cinco casos de meningite criptocócica em crianças com síndrome da imunodeficiência adquirida (AIDS). Arq. bras. Pediat., 4: 15-20, 1997

13. ROZENBAUM, R. \& GONÇALVES, A.J.S. - Clinical epidemiological study of 171 cases of cryptococcosis. Clin. infect. Dis., 18: 369-380, 1994.

14. SANTOS, A.; OLIVEIRA, M.Y.S.; MOURA, E.F.A. \& OHANA, B. - Criptococose Apresentação de um caso clínico em criança de baixa idade. J. Pediat., 53: 183-186, 1982.

15. SPEED, B. \& DUNT, D. - Clinical and host differences between infections with the two varieties of Cryptococcus neoformans. Clin. infect. Dis., 21: 28-34, 1995.

16. SPEED, B.R. \& KALDOR, J. - Rarity of cryptococcal infection in children. Pediat. infect. Dis. J., 16: 536-537, 1997.

Received: 20 March 2002

Accepted: 23 August 2002 